Western University Scholarship@Western

Centre for the Study of International Economic Centre for the Study of International Economic

Relations Working Papers

Relations

1986

\title{
Inside Money, Output, and Causality
}

Scott Freeman

Gregory W. Huffman

Follow this and additional works at: https://ir.lib.uwo.ca/economicscsier_wp

Part of the Economics Commons

Citation of this paper:

Freeman, Scott, Gregory W. Huffman. "Inside Money, Output, and Causality." Centre for the Study of International Economic Relations Working Papers, 8622C. London, ON: Department of Economics, University of Western Ontario (1986). 
ISSN $\quad 0228-4235$

ISBN $0-7714-0767-\mathrm{X}$

THE CENTRE FOR THE STUDY OF INTERNATIONAL ECONOMIC RELATIONS

WORKING PAPER NO. $8622 \mathrm{C}$

INSIDE MONEY, OUTPUT, AND CAUSALITY

Departinent of Economics Library

Scott Freeman

and

Gregory W. Huffman

SEP 161986

University of Western Ontario

This paper contains preliminary findings from research work still in progress and should not be quoted without prior approval of the authors.

DEPARTMENT OF ECONOMICS

THE UNIVERSITY OF WESTERN ONTARIO

LONDON, ONTARIO

N6A $5 \mathrm{C} 2$ 


\section{INSIDB MONEY, OUTPUT, AYD GAUSALITY}

Scott Freeman and Gregory $w$. Huffman

Boston College and University of Western Ontario

August, 1986 


\section{IMTRODUCTION}

The observed correlation between nominal money stock and real output (e.g., Friedman and Schwartz (1963a, b) and Sims (1972)) has attracted a great deal of attention among macroeconomists. The evidence, especially the precedence of money shocks to output shocks, leads one to speculate on whether the business cycle is caused by randomness in the money stock and whether deliberate changes in the fiat money stock may be used to effect changes in output.

There is however, evidence (Cagan (1965), King and Plosser (1984)) which suggests that it is primarily inside money that is correlated with output, implying that the observed nominal money shocks may represent endogenous reactions of the money stock to changes in output or to some third force causing the changes in both money and output. This view was encouraged by the work of sims (1980) and Litterman and Weiss (1985), who showed that when interest rates were included in vector autoregressions, interest rate innovations and not those of money were found to precede the larger part of innovations in output.

Although most of the money stock is inside money and most of the money/output correlation seems related to inside money fluctuations, most attempts to explain the money/output correlations have featured fiat money as the only form of money. ${ }^{1}$ The model of this paper looks at money/output correlations where the stock of money consists of both inside and outside money (deposits plus currency at the Federal Reserve's, M1). The model's money multiplier is endogenous, determined by the relative returns and transactions costs of inside money and fiat money. Inside money 
represents deposits at banks, which use the deposits to create capital (or equivalently, to make loans to agents who create capital). It will be useful, therefore, to think of inside money as intermediated capital.

Environmental changes that make the holding of intermediated capital more attractive increase both the current money stock (through an increase in the ratio of inside to outside money) and subsequent output (through an increase in current capital). The model in many ways displays a money/output correlation like that of the data even though the changes in both money and output represent endogenous reactions to changes in some third factor. Therefore, the observed changes in the money stock are changes in the nominal stock of inside money that precede, but do not "cause", the changes in output. A change in the money stock resulting from a change in the stock of fiat money alone will not lead to any change in output.

The times series generated by the model are also consistent with the findings of Sims (1980) and Litterman and Weiss (1985) concerning nominal and real interest rates, respectively. Both nominal and real interest rates, like money, are affected by the environmental shocks before output is affected. When there are both shocks to the physical environment and the monetary base, it is the interest rate (either real or nominal), not money, that emerges as firmly Granger-causally prior to output in vector autoregressions of the interest rate, money, and output.

The remainder of this paper is organized as follows. In section I the physical environment of the model is specified. The method by which agents can undertake intertemporal exchanges is described. Lastly the equilibrium of the model is described. Section II of the paper is used to show how exogenous disturbances can affect the time series properties of endogenous variables. 
Conclusions are contained in Section III, and proofs are in Appendix A. In Appendix B we present a simulation which illustrates the models ability to mimic some of the facts described above.

\section{THE RODBL}

\section{The Rnvironment:}

In each period $t \geq 1$ a continuum of two-period lived agents is born. Each agent at $t$ acts to maximize his expected lifetime utility, given by $U\left(c_{1 t}\right)+\beta_{t} E_{t} c_{2 t}$, where $c_{i t}$ represents consumption by a member of generation $t$ in the $i^{\text {th }}$ period of 1 ife and $E_{t}$ represents the expectation operator conditioned on information available at $t$. The value of the positive parameter $\beta_{t}$ is known at $t$. The function $U(\cdot)$ is twice-continuously differentiable, increasing, and concave with $\lim _{c \rightarrow 0} U^{\prime}(c)=\infty$.

In each generation there are two types of agents: "regular" agents and "prominent" agents. Each regular agent $i$ of generation $t \geq 1$ is endowed with $y_{t}^{i}$ units of non-storable labor. Each unit of labor is used inelastically to produce one unit of the economy's sole consumption good. There is a continuum of regular agents in each generation. The population of regular agents is normalized to equal unity. In each generation $t \geq 1$ the distribution of endowments $y_{t}^{1}$ is described by the uniform density function $\theta\left(y_{t}^{1}\right)=1$ for $y_{0}<y_{t}^{i} \leq \bar{y}$ and $\theta\left(y_{t}^{i}\right)=0$. The parameters $y_{0}$ and $\bar{y}$ are positive constants. The identity of a regular agent is costlessly known only to himself. Others can learn a regular agent's identity only at a fixed cost of $\gamma$ units of the consumption good. 
Prominent agents are costlessly identified by all. They have no endowment of labor but have access to the following capital technology to which regular agents do not have access. The number of prominent agents is sufficient to ensure a competitive equilibrium.

A unit of the consumption good at $t$ that is not consumed may be used to create a unit of capital. A unit of capital created at $t$ produces $x_{t}$ units of the consumption good at $t+1$. The value of $x_{t}$ is a function of the aggregate amount of capital created at $t\left(K_{t}\right): x_{t}=\alpha_{t} X\left(K_{t}\right)$, where $\alpha_{t}$ is a positive constant and where $X(\cdot)$ is continuously differentiable and decreasing with

$\lim _{K \rightarrow 0} X(K)=\infty$, and $\left[X(K)+K X^{\prime}(K)\right]>0$ for $K>0$ (i.e. $X(K) K$ is increasing in $\mathrm{K}$ ).

There exists a fixed stock of fiat money, which is intrinsically useless, unbacked, noncounterfeitable, and costless to exchange. $M_{t}$ will denote the quantity of fiat money outstanding during period $t$. At the beginning of period 1 , all fiat money is owned by the "current old", who may be considered generation 0 . The current old live only in period 1 and seek only to maximize personal consumption in that period. To ensure a demand for fiat money, the government enforces (costlessly) a legal prohibition on the issue and use of privately issued bearer notes.

\section{Yedia of Exchange:}

The basic problem facing regular agents is how to arrange for consumption when they are not endowed. One option is to purchase fiat money from old agents to be sold for goods when the purchaser is himself old. A second option is to deposit goods with a prominent agent, who can create capital from which a return can be paid in the next period. In a competitive 
equilibrium, deposits will pay the rate of return on capital. To collect this return, the regular agent must return to the prominent agent and identify himself (an action that uses up $Y$ goods). Recall that agents are legally prohibited from purchasing notes or IOU's that are payable to the bearer.

The reader may wish to interpret a deposit of goods with a prominent agent as a deposit at a bank or some similar financial intermediary. The cost $\gamma$ may then be interpreted as the cost or bother of identifying oneself in person at the bank or of identifying oneself by the writing of a check. The legal restriction may be considered a prohibition on private banknotes, like the restrictions present in most modern economies.

\section{Bquilibrium:}

The problem of a regular agent born at $t$ and endowed with $y$ who holds only inside money (bank deposits) is to choose non-negative consumption and real balances of inside money, $h_{t}$, to maximize $U\left(c_{1 t}\right)+\beta_{t} E_{t} c_{2 t}$ subject to

$$
y=h_{t}+c_{1 t} \text { and } x_{t} h_{t}-r=c_{2 t} \text {. }
$$

since the agent knows $x_{t}$ and $\gamma$ when he makes his decision. The (necessary and sufficient) first order condition for a maximum is:

$$
-U^{\prime}\left(y-h_{t}\right)+x_{t} \beta_{t}=0 \text {. }
$$

The problem of a regular agent born at $t$ and endowed with $y$ who holds only fiat money is to choose non-negative consumption and real balances of fiat money, $q_{t}$, to maximize $U\left(c_{1 t}\right)+\beta_{t} E_{t}\left(c_{2 t}\right)$ subject to

$$
y=q_{t}+c_{1 t} \quad \text { and } p_{t} q_{t}=c_{2 t}
$$

where $\rho_{t}$ is the gross real rate of return of $f$ iat money purchased at $t$. The necessary and sufficient first order condition for a maximum is:

$$
-U^{\prime}\left(y-q_{t}\right)+\beta_{t} E_{t}\left(p_{t}\right)=0
$$


It remains to describe the extent of the holding of inside and outside money in equilibrium. The assumption $\lim _{K \rightarrow 0} X(K)=\infty$ guarantees that a positive amount of inside money is held in equilibrium (see Lemma 1 in the appendix). We will confine our attention to equilibria in which $y_{0}$ is sufficiently large that every agent desires to consume a positive amount in the second period of life.

The average rate of return, including transaction costs, of inside money acquired at $t$ is $\left(x_{t} h_{t}-\gamma\right) / h_{t}$ or $x_{t}-\gamma / h_{t}$, where $h_{t}$ denotes the real quantity of inside money balances held by an agent. Note that the rate of return on inside money is an increasing function of an individual's inside money balances. Since regular agents differ only in the size of their endowment and since desired money balances are an increasing function of the endowment, inside money is more attractive the larger an agent's endowment. Since both inside and fiat money will be held in equilibrium and there is a continuum of endowments, we can identify a borderline endowment $y_{t}^{*}$ above which all regular agents at $t$ hold inside money and below which all hold fiat money. This borderline endowment is defined implicitly as the endowment at which the utility of an agent choosing inside money is just equal to the utility of an agent choosing fiat money:

$U\left(y_{t}^{*}-h_{t}\left(y_{t}^{*}\right)\right)+\beta\left(x_{t} h_{t}\left(y_{t}^{*}\right)-\gamma\right)=U\left(y_{t}^{*}-q_{t}\left(y_{t}^{*}\right)\right)+\beta_{t} E_{t}\left(p_{t} q_{t}\left(y_{t}^{*}\right)\right)$ where $h_{t}\left(y_{t}^{*}\right)$ and $q_{t}\left(y_{t}^{*}\right)$ are the values of $h_{t}$ and $q_{t}$ that satisfy the first order conditions (2) and (4) with $y_{t}=y_{t}^{*}$.

A final equilibrium condition is the clearing of the market for fiat money. Define $p_{t}$ as the price of a unit of the consumption good in units of fiat money. Then 


$$
u_{t}=p_{t} Q_{t} \equiv p_{t} \int_{y_{0}^{t}}^{y_{t}^{*}} q_{t} d y
$$

It follows that the rate of return of fiat money is $p_{t}=p_{t} / p_{t+1}=Q_{t+1} / Q_{t}$.

The essential equilibrium conditions can be sumnarized as the following implicit functions:

$F_{1}\left(K, h, Q, q, y^{*}\right) \equiv K-\int_{y}^{\bar{y}} h d y=0$

$F_{2}\left(K, h, Q, q, y^{*}\right) \equiv-U^{\prime}(y-h)+\alpha X(K) \beta=0$

$F_{3}\left(K, h, Q, q, y^{*}\right) \equiv Q-\int_{y_{0}}^{y^{*}} q d y=0$

$F_{q}\left(K, h, Q, q, y^{*}\right) \equiv-U^{\prime}(y-q)+\beta(\bar{Q} / Q)=0$

$F_{5}\left(K, h, Q, q, y^{*}\right) \equiv U\left(y^{*}-h\right)+\beta(\alpha X(K) h-\gamma)-U\left(y^{\star}-q\right)-\beta(\bar{Q} / Q) q=0$

where all variables are evaluated at the current period (although the time subscripts have been suppressed to ease the notational burden.

$\bar{Q}$ denotes the expected value of $Q$ in the next period.

\section{BOUILIBRIUY TIME SERIES}

We can now describe properties of the equilibrium time series under a variety of stochastic shocks in order to compare them to the time series properties outlined in the introduction. 
To compare the time series of the model to those of the real world we need to define measures of output, the money stock and interest rate. Real output at $t$ is defined to be the sum of output at $t$ from labor and from capital or:

$$
\begin{aligned}
\mathrm{GNP}_{t} & \equiv \int_{y^{y}}^{\bar{y}} y d y+x_{t-1} k_{t-1} \\
& \left.=-\frac{\bar{y}^{2}-y^{2}}{2}+\alpha_{t-1} x_{t-1}\right) k_{t-1}
\end{aligned}
$$

Note that because the labor decision is trivial, output is solely a function of the previous period's capital stock. The nominal money stock at $t$ is the sum at $t$ of deposits of intermediaries and currency (fiat money) or:

$$
\begin{aligned}
\text { MS }_{t} & \equiv M_{t}+K_{t} P_{t} \\
& =M_{t}\left(1+K_{t} / Q_{t}\right)
\end{aligned}
$$

from the market clearing condition for fiat money $P_{t} Q_{t}=M_{t}$. The real interest rate at $t$ is $\alpha_{t} X\left(K_{t}\right)$ and the expectation at $t$ of the rate of inflation is $E_{t}\left(Q_{t} / Q_{t+1}\right)$. For a given stock of $f$ iat money, the total nominal money money stock is determined by the ratio of inside to outside money, $K_{t} / Q_{t}$. If shocks to real balances of fiat money are serially uncorrelated, $E_{t}\left(1 / Q_{t+1}\right)$ is a constant and expected inflation is an increasing linear function of current real balances, $Q_{t}$. From the above definitions the nominal interest rate $\alpha_{t} X\left(K_{t}\right) E_{t}\left(Q_{t} / Q_{t+1}\right)$ can be constructed. 


\section{Endogenous Changes in the Honey Stock}

Let us first examine the time series properties of an economy where the marginal product of capital, $x_{t}=\alpha_{t} X\left(K_{t}\right)$ is random because the parameter $\alpha_{t}$ is a serially uncorrelated random variable, (but always positive). The main properties of such an equilibrium are sumnarized in Proposition 1.

Proposition 1: A positive innovation to the productivity of capital created at $t$ causes a contemporaneous positive innovation to the capital stock ( $\left.K_{t}\right)$ and the nominal money stock ( $\mathrm{MS}_{t}$ ), and a subsequent positive innovation to output (GNP $t+1$ ).

The intuition underlying these results is quite simple (the actual proof is presented in Appendix A). A positive shock to the marginal product of capital makes inside money, deposits backed by capital, more desirable than usual relative to unbacked fiat money. The increase in real balances of inside money and the decrease in real balances of $\mathrm{fiat}$ money imply an increase in the "money multiplier" $(1+K / Q)$ and therefore an increase in the nominal money stock. Moreover, because current capital increases, next period's output will rise. Therefore, the model displays the precedence of money supply shocks to output shocks as the result of an endogenous change in the money multiplier.

It is important to note that the money stock shocks displayed by this equilibrium represent changes in inside money balances, not changes in the stock of fiat money. In this regard the equilibrium is consistent with the findings of Cagan (1965) and King and Plosser (1984) that the money/output correlation is in great part a correlation between inside money balances (or "the money multiplier") and output. 
Because the shocks are serially uncorrelated, a drop in current real balances of fiat money (Q) implies that the expected rate of return on fiat money $(\bar{Q} / Q)$ rises and the expected inflation rate $(Q / \bar{Q})$ falls. Because the real rate of interest rises, and the expected inflation rate falls, the effect of a positive shock to $\alpha$ on the nominal interest rate is ambiguous. Therefore, although shocks to the productivity of capital are able to account for the money/output correlations observed by sims (1972) and may also account for the positive correlations between the nominal interest rate and output, it does not account for the negative correlation between output and the real interest rates as measured by Litterman and Weiss (1985). A simulation of the model which uses shocks to the marginal product is described, along with the simulation technique, in Appendix B.

Now let us study the model's time series when there are serially uncorrelated fluctuations in the transaction cost $\gamma$.

Proposition 2: A negative innovation in the transaction cost $(\gamma)$ faced by the generation born at $t$ causes an increase in the capital created at $t\left(K_{t}\right)$, the nominal money stock at $t\left(\mathrm{MS}_{t}\right)$, and output at $t+1\left(\operatorname{GNP}_{t+1}\right)$, while causing decreases in the real and nominal interest rates at $t$ as well as the expected inflation rate $E_{t}\left(Q_{t} / Q_{t+1}\right)$. (Proof in Appendix $A$ ).

The effects of shocks to the transaction cost follow from the resulting change in the relative desirability of inside and outside money. A drop in the cost of using inside money increases its attractiveness relative to fiat money, increasing real balances of inside money and reducing real balances of outside money. Together they imply an increase in the nominal money supply. 
The increase in inside money represents an increase in capital, which causes both the increase in subsequent output and the reduction in the real interest rate.

The decrease in real balances of fiat money implies an increase in the price level and decreases in expected inflation as well as the nominal interest rate. Therefore, a positive innovation to the transaction cost parameter unambiguously accounts for the interest rate correlations as presented by Litterman and Weiss (1985).

Finally, let us examine the effects of a shock to the demand for all money balances in the form of a shock to $\beta$.

Proposition 3: In an economy where $\beta_{t}$ is a serially uncorrelated random variable, innovations in $\beta_{t}$ are positively correlated with innovations in the level of real deposits (capital) at $t$, negatively correlated with changes in the real interest rate at $t$, and positively correlated with changes in output in the subsequent period.

The proof of Proposition 3 is contained in Appendix A but we will outline here the equilibrium forces leading to these results. A positive shock to $\beta_{t}$ means that agents will wish to consume more in the second period of their lives. As a result they hold greater balances of money and a larger fraction of the population will wish to use inside rather than outside money. The real stock of inside money will therefore increase both because those using inside money hold more money and because fewer agents choose to use fiat money. The effect of the shock on the real stock of fiat money, however, is ambiguous since fewer agents choose fiat money but those who do hold more. 
The increased use of deposits results in a greater current capital stock, which lowers the current real rate of interest (since $X^{\prime}(K)<0$ ) and raises real output in the subsequent period.

The effects of the shock on the current total nominal money stock depend on what happens to the ratio $\mathrm{K}_{t} / Q_{t}$ (as can be seen in (9)). If real balances of fiat money fall, the total nominal money stock rises. If not, the nominal money stock will still rise if the percentage increase in real balances of fiat money is less than that of deposits. If real balances of fiat money fall, the current price level rises and expected inflation falls. As a result the nominal interest rate also falls.

In the case that real balances of fiat money fall, the time series of this economy display properties listed in the introduction and found in postwar data by Sims and Litterman and Weiss: vector autoregressions (VAR's) involving only money and output will display a precedence of money stock shocks to output shocks. If real or nominal interest rates are included in the VAR, shocks to them will also be seen to precede output. In addition, the model displays negative correlations between the real interest rate and the money stock and between the real interest rate and future output, all of which is found in the data studied by Litterman and Weiss.

\section{Changes in the Eonetary Base}

All of the monetary fluctuations described above resulted from fluctuations in the money multiplier. Those who take seriously monetary aggregates like $M 1$ and $M 2$ believe that the correlation between such measures and output must be essentially the same whether the money stock fluctuations 
result from changes in the money multiplier or in the monetary base. Let us therefore examine the time series properties of this model when the monetary base is random.

Let us first suppose that the monetary base $\left(K_{t}\right)$ changes according to the rule $M_{t}=z_{t} M_{t-1}(t \geq 1)$ where $z_{t}(z 1)$ is a serially uncorrelated random which is also independent of all other exogenous disturbances. The realization of $z_{t}$ is not known before $t$; more precisely, $B_{t-i} z_{t}=\bar{z}$, a constant greater than one for $i>0$. Assume that any expansion of the fiat money stock $\left(z_{t}>1\right)$ is used to finance government purchases of the consumption good, which are disposed of in a way that does not affect the utility of any agent.

Proposition 4: Output is entirely uncorrelated with serially uncorrelated shocks to the monetary base such that $E_{t-i} z_{t}=\bar{z}$ for $i>0$.

The intuition underlying Proposition 4 is sufficiently obvious that no formal proof will be presented. Simply note that the attractiveness of fiat money depends on its expected rate of return, which is a function of the expected future rate of fiat money creation $(\bar{z})$ but not the current realization of the fiat money stock. Since the future money supply growth rate is unrelated to any shocks to the current fiat money stock, the real values of the current money decisions $\left(K_{t}\right.$ and $\left.Q_{t}\right)$ as well as output and investment will be unaffected by the current nominal fiat money stock.

In Propositions 1, 2 and 3 we examined a variety of possible causes for both interest rates and the money stock to precede output. They did not explain, however, why it is that when either the real or nominal interest rate 
and the money stock are included with output in a vector autoregression, it is primarily innovations in the interest rate, not the money stock, that are observed to precede innovations in output. The results of Proposition 4 may help to explain why this may be so.

Consider an economy with both shocks to one of the real parameters $a$, $\beta$, or $\gamma$ and independent shocks to $z$. Output and the interest rate will change only when there is a shock to a real parameter, but the money stock will change both when there is a shock to a real parameter (changing the money multiplier) and when there is a shock to the monetary base. There will be a strong correlation between the interest rate and output since each changes only when the other changes and a weaker one between money and output because there are changes in the money stock that are not linked to changes in output. Therefore, in a VAR with only money and output, money innovations will be important for predicting output; but if the interest rate is included in the VAR the money stock will lose some of its importance in the regression. This notion is illustrated in Appendix B which contains a simulation of an economy in which there exists both nominal and real shocks. This neutrality of the monetary base is not obtained when the rate of fiat money creation is known in advance. To see this, let us maintain all our previous assumptions except to let $E_{t-1} z_{t}=z_{t}$ and $E_{t-i} z_{t}=\bar{z}$ for $i>1$. The time series properties of such an economy are presented in the following proposition.

Proposition 5: An anticipated positive shock to next period's rate of fiat money creation causes an increase in the current capital stock, the current nominal money stock, and subsequent output and a decrease in the current real interest rate. (Proof in Appendix A). 
Again, the intuition underlying this result is simple. An increase in the expected rate of fiat money creation lowers the expected rate of return on fiat money. Some agents therefore switch from fiat money to inside money, increasing the money multiplier (even before the base is expanded) and the stock of intermediated capital. The increased capital leads to a lower current real interest rate and greater output next period. The effect on the nominal interest rate is ambiguous because the real interest rate declines while expected inflation is rising.

Proposition 5 also suggests how it may be that an increase in the current monetary base may precede an increase in output. If the rate of fiat money creation is positively serially correlated, an innovation in the current monetary base will signal an increased likelihood of inflation next period as well, thereby encouraging some agents to switch to inside money, which reduces the current real interest rate and increases subsequent output. Although triggered by the observed shock to the monetary base, the direct cause of these effects is a change in the public's preference for inside money. In this way the model suggests a mechanism through which changes in the monetary base may affect output.

\section{Stabilization of the Money stock}

A common interpretation (which we label "monetarism") of the money/output correlation is that fluctuations in the money stock contribute to fluctuations in output in the sense that if the money stock fluctuations were eliminated, output fluctuations would be reduced or eliminated [e.g. Friedman (1968)]. The monetarist policy in the face of output fluctuations is therefore to compensate for any changes in the money multiplier with changes 
in the monetary base. In the model presented here, the monetarist policy will not reduce output fluctuations. Recall, for example, the effects of a positive shock to $\alpha$. The higher rate of return on intermediated capital makes inside money more desirable, increasing the money multiplier, and encourages the holding of capital, raising future output. The total nominal money stock can be held constant in this situation only if the current stock of fiat money declines. However, a decline in the current monetary base does nothing to alter any choice problem in real terms and so fails to affect such endogenous variables as capital and output. Therefore, any real fluctuations caused by the shock to $\alpha$ (or any other environmental parameter) will be undampened by changes in the monetary base. 2

Remarks on the Environment

The key feature of this economy is that there exists inside money backed by capital. When a change in the economy encourages agents to switch from fiat to inside money, there is an increase in the total nominal money stock and in the extent of capital-holding, which increases subsequent output. So long as some part of inside money is backed by capital, a variety of environments will display this endogenous correlation between money and output. For example, abandoning the simplifying assumption that all capital is in the form of inside money would not change the results. Imagine that there exist separate demands for both nonintermediated capital and intermediated capital (inside money). The simplest way to do this in the context of the model presented is to assume that prominent agents, who do not need to use intermediaries to hold capital, have endowments of their own, 
some of which they use to create capital. In such an economy, environmental changes that make all capital more desirable (such as an increase in $\alpha$ or $\beta$ ) will increase holdings of both intermediated and unintermediated capital, increasing subsequent output, and the current nominal money stock.

Other features of the model were also chosen so that the equilibrium can be clearly described but are not essential to the model's conclusions. For example, the cause of the illiquidity of capital is not important so long as some form of intermediation will allow it to serve as backing for deposits. The finite lifespan is also not an essential assumption. A version of the model featuring infinitely lived but spatially separated agents as in Townsend (1980) would yield the same money/output correlations so long as both inside and outside money were used as money. Indeed the source of the demand for money is not crucial. Models with money balances in the utility function or models where the advance acquisition of money is required for all transactions will have similar implications so long as some of what is defined to be money is intermediated capital. ${ }^{3}$ The money/output correlation comes from changes in the composition of money balances, not the level of the balances nor from why those balances are held.

\section{CONCLUSIONS}

The preceding analysis emphasizes that the statistical causality tests, as used in sims (1972), may yield deceiving results. The finding that "money" is Granger-causally prior for aggregate output does not necessarily imply that policy-induced changes in the money supply will significantly influence future output. There may be components of the money stock that are not under the direct control of the policymaker, but which account for the correlation 
between the money supply and future changes in the level of output. The model, like the work of Sargent and Wallace (1982), highlights the idea, which is becoming pervasive in the literature, that inside and outside money should not be aggregated. These variables are determined by different factors and exhibit different correlations with other endogenous aggregates. Aggregation of these variables is misleading insomuch as it presumes that both factors exhibit the same correlations with other aggregates. 


\section{APPEI:DIX A}

Lemma 1: In an equilibrium with valued fiat money $(Q>0), X(K)>\bar{Q} / Q$ and $\mathrm{K}>0$.

Proof: It cannot be that $X(X) \leq \bar{Q} / Q$. There is a transaction cost $Y$ attached to the use of inside money. Therefore, if $x(K) \leq \bar{Q} / Q$ the rate of return of fiat money would dominate that of inside money for every agent, implying that $K=0$. But $X(0)=\infty$, which is greater than $\bar{Q} / Q$, which must be finite since $Q>0$ and $\bar{Q}$ can be no greater than the finite total endowment of goods.

Lerma 2: In equilibrium, $h^{*}>q^{*}$.

Proof: From Lemma 1, $x>\bar{Q} / Q$. From $F_{2}$ and $F_{4}, x=U^{\prime}\left(y^{*}-h^{*}\right)$ and $\bar{Q} / Q=U^{\prime}\left(y-q^{*}\right)$. Therefore, $U^{\prime}\left(y^{*}-h^{\star}\right)>U^{\prime}\left(y^{\star}-q^{\star}\right)$, implying that

$\mathbf{h}^{*}>\mathbf{q}^{*}$. Q.E.D.

Lemma 3: The Jacobian of the equilibrium conditions ( 7 ) is positive.

Proof: The Jacobian of (7), which will be denoted $D$, is: 


$\begin{array}{|lcccc|}1 & y^{*}-\bar{y} & 0 & 0 & h^{*} \\ X^{\prime} \beta U^{\prime} & U^{\prime \prime} & 0 & 0 & 0 \\ 0 & 0 & 1 & y^{*} & -q^{*} \\ 0 & 0 & -\beta \bar{Q} / Q^{2} & U^{\prime \prime} & 0 \\ X^{\prime} \beta h^{*} & 0 & \beta q^{*} \bar{Q} / Q^{2} & 0 & D_{55}\end{array}$

Note that the above expression makes use of the first order conditions to determine that

$$
\begin{aligned}
& \frac{\partial F_{5}}{\partial h}=-U^{\prime}\left(y^{*}-h^{*}\right)+\beta x=0 \\
& \frac{\partial F_{5}}{\partial q}=-U^{\prime}\left(y^{*}-q^{\star}\right)+\beta \frac{\bar{Q}}{Q}=0
\end{aligned}
$$

Horeover,

$$
\frac{\partial F_{5}}{\partial y^{*}} \equiv D_{55}=U^{\prime}\left(y^{*}-h^{*}\right)-U \cdot\left(y^{*}-q^{*}\right)>0
$$

$$
\text { since } h^{*}>q^{*}(\text { see Lemma } 2) \text {. }
$$

From cofactor expansion we can find that

$$
D=X^{\prime} B U^{\prime}\left(\bar{y}-y^{*}\right) A+U^{\prime \prime} A-U^{\prime \prime} X^{\prime} \beta\left(h^{*}\right)^{2}\left[U^{\prime \prime}-y^{*} \beta \bar{Q} / Q^{2}\right]
$$

where $A \equiv U^{\prime \prime q} \beta q^{\star}{ }^{\star} \bar{Q} / Q^{2}+\frac{\partial F}{\partial y^{\star}}\left[U^{\prime \prime}-y^{*} \beta \bar{Q} / Q^{2}\right]$ 
When the signs of all the terms are evaluated, $A<0$ and $D>0$. Q.B.D.

\section{Proof of Proposition 1:}

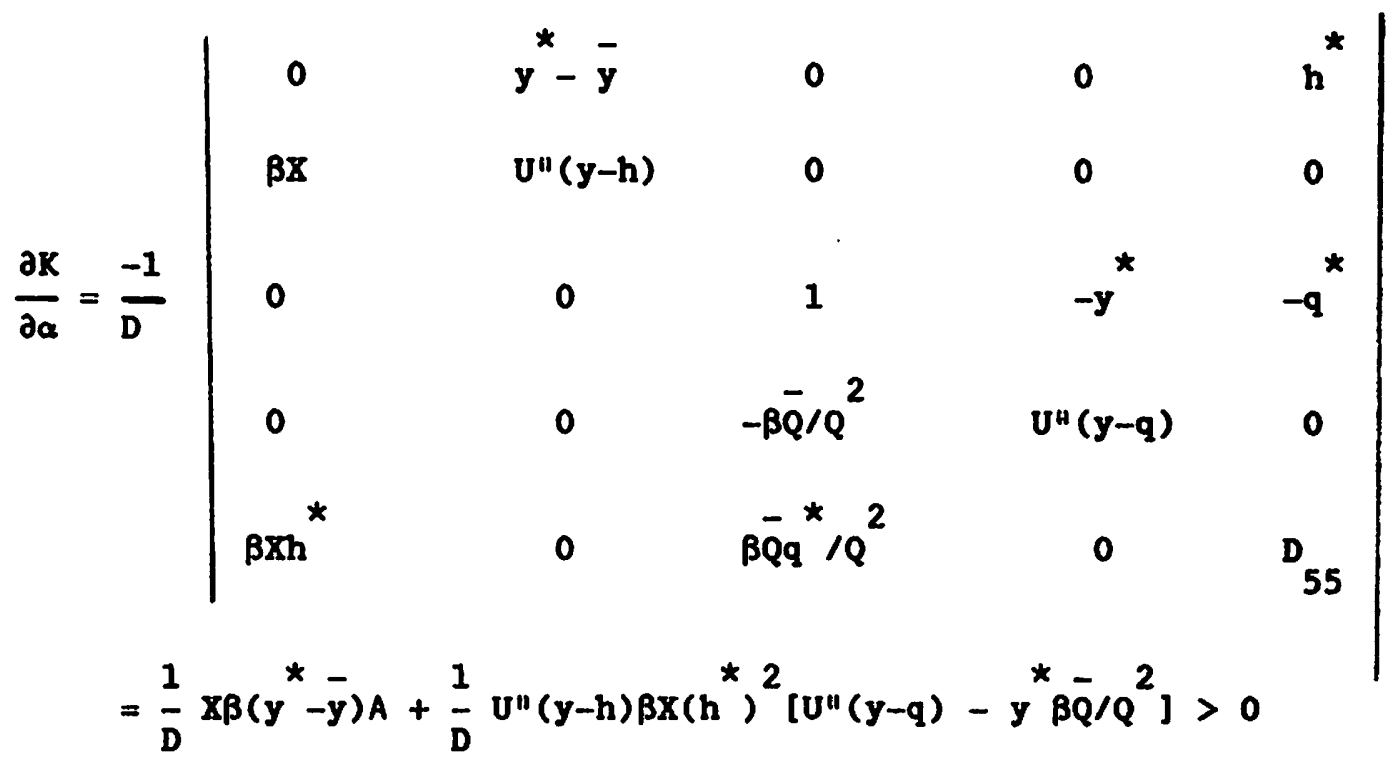

because $A<0$ and $D>0$ (from Lemma 3 ).

$$
\text { Recall that GNP' } \left.\equiv \operatorname{GNP}_{t+1}=\left(\frac{\mathrm{y}^{-2}-y^{2}}{2}\right)+\alpha \mathrm{XX}_{t}\right) \cdot K_{t} \text {. }
$$

$\therefore \frac{\partial \text { GNP }^{\prime}}{\partial \alpha}=\mathrm{X}(\mathrm{K}) \mathrm{K}+\frac{\partial \mathrm{K}}{\partial \alpha} \alpha\left[\mathrm{X}(\mathrm{K})+\mathrm{KX}^{\prime}(\mathrm{K})\right]>0$ because $\mathrm{X}(\mathrm{K})+\mathrm{KX}^{\prime}(\mathrm{K})>0$ by assumption.

$\frac{\partial Q}{\partial \alpha}=\frac{-1}{D}\left|\begin{array}{ccccc}1 & y^{*}-y & 0 & 0 & h^{*} \\ \beta \alpha X^{\prime} & U^{\prime \prime}(y-h) & X \beta & 0 & 0 \\ 0 & 0 & 0 & -y^{*} & -q^{*} \\ 0 & 0 & U^{\prime \prime}(y-q) & 0 \\ \beta \alpha X^{*} h^{*} & 0 & X^{*} & 0 & D_{55}\end{array}\right|$




$$
\begin{aligned}
& =\frac{-1}{D} U^{\prime \prime}(y-q) q^{*}\left[X \beta^{2} \alpha X^{\prime} h^{*}\left(y^{*}-\bar{y}\right)+X_{\beta h}{ }^{*}\left[U^{\prime \prime}(y-q)-\left(y^{*}-\bar{y}\right) \beta \alpha X^{\prime}\right]\right. \\
& =-\frac{1}{D}\left(U^{\prime \prime}(y-q)\right)^{2} q^{*} X \beta h^{*}<0 .
\end{aligned}
$$

Since $\frac{\partial Q}{\partial \alpha}<0$ and $\frac{\partial K}{\partial \alpha}>0$, it must be that $\frac{\partial(\text { MS })}{\partial \alpha}>0($ from $(9))$.

Q.B.D.

Proof of Proposition 2:

$\frac{\partial K}{\partial \gamma}=\frac{-1}{D}\left|\begin{array}{ccccc}0 & y^{*-\bar{y}} & 0 & 0 & h^{*} \\ 0 & U^{\prime \prime}(y-h) & 0 & 0 & 0 \\ 0 & 0 & 1 & -y^{*} & { }^{*} \\ 0 & 0 & -\beta \bar{Q} / Q^{2} & U^{\prime \prime}(y-q) & 0 \\ -\beta & 0 & B \overline{Q q}^{*} / Q^{2} & 0 & D_{55}\end{array}\right|$

$$
=-\frac{\beta}{D} U^{\prime \prime}(y-h) h^{*}\left[U^{\prime \prime}(y-q)-y^{*} \beta \bar{Q} / Q^{2}\right]<0
$$

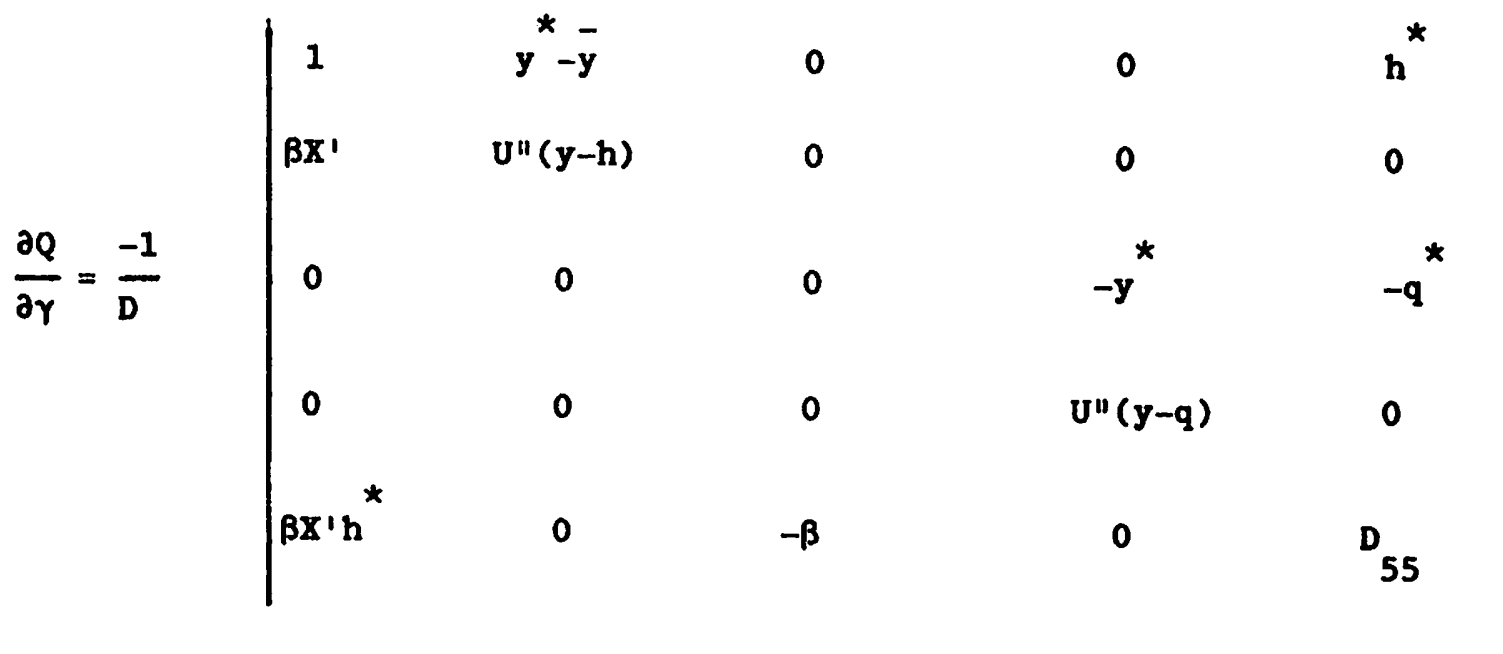




$$
=\frac{\beta}{D} U^{\prime \prime}(y-q) q^{*}\left[U^{\prime \prime}(y-h)-\beta X^{\prime}\left(y^{*}-\bar{y}\right)\right]>0
$$

The effects on output and the nominal money stock, and the other variables easily follow (see the proof of Proposition 1).

\section{Proof of Proposition 3:}

For convenience we set $\alpha=1$. Using the implicit function theorem, we find that

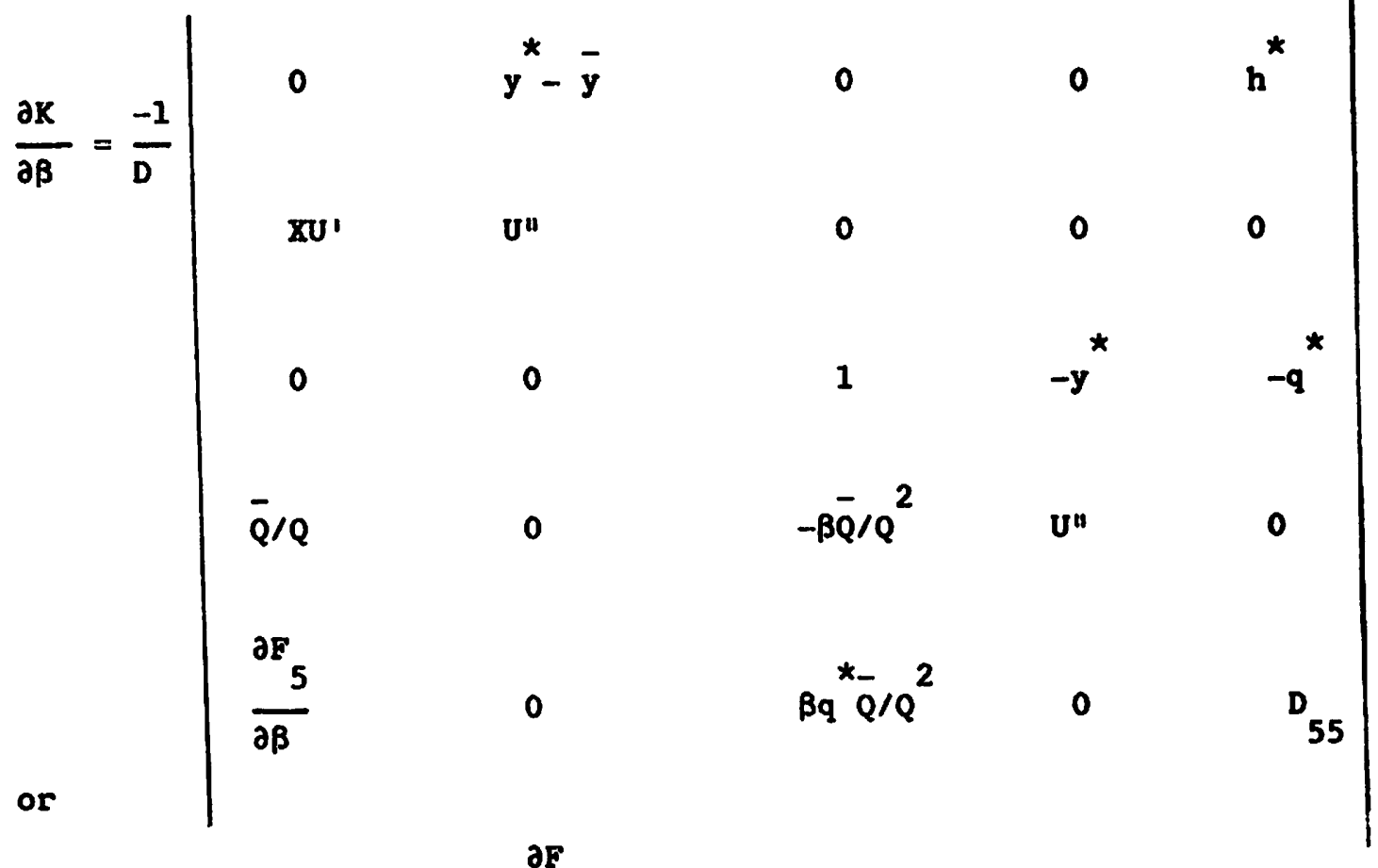

$$
\begin{aligned}
& \frac{\partial K}{\partial \beta}=x U^{\prime}\left(y^{*}-\bar{y}\right) A / D+\frac{5 F}{\partial \beta} h^{*}\left(U^{\prime \prime}\right)^{2} / D \\
& -U^{\prime \prime y}{ }^{*} h^{*}\left[(\bar{Q} / Q)\left(\beta q{ }^{*} \bar{Q} / Q^{2}\right)-\frac{\partial F}{\partial \beta} \beta \bar{Q} / Q^{2}\right] / D,
\end{aligned}
$$


where $\frac{\partial F}{\partial \beta}=U\left(X h^{*}-\gamma\right)-q^{*} Q / Q$. Since $h^{*}>q^{*} \operatorname{implies} U\left(y^{*}-h^{*}\right)$ $<U\left(y^{*}-q\right)$ equation (5) implies $U\left(X_{h}^{*}-\gamma\right)>q^{*} Q / Q$. Since $U\left(y^{*}-h^{*}\right)<$ $U\left(y^{*}-q^{\star}\right)$ for $h^{*}>q^{*}, \frac{\partial F}{\partial \beta}>0$ for equation $F_{5}$ to hold.

When the signs of the terms (including $A$ and $D$ calculated in Lemma 3 )

are evaluated, it can be seen that $\frac{\partial K}{\partial \beta}>0, i . e .$, a positive shock to $\beta$ leads to a positive shock in current capital. A larger capital stock implies a lower real interest rate (because $X^{\prime}(K)<0$ ) and greater output one period later (from $(8)$ and $\left.X(K)>-X^{\prime}(K) K\right)$ Q.B.D.

\section{Proof of Proposition 5}

Market clearing implies $\mathbf{M}_{t}=\mathbf{p}_{t} \mathbf{Q}_{t}$. It follows that $p_{t}=$ $\frac{P_{t}}{P_{t+1}}=\frac{{ }_{t}^{M} / Q_{t}}{M_{t+1} / Q_{t+1}}=Q_{t+1} / Q_{t} z_{t+1}$. Therefore, the equilibrium conditions $F_{4}$ and $F_{5}$ must be modified to read:

$$
\begin{aligned}
& F_{4}\left(K, h, Q, q, y^{*}\right) \equiv-U^{\prime}(y-q)+\beta\left(\overline{\left.Q^{\prime} / Q z\right)}=0\right. \\
& F_{5}\left(K, h, Q, q, y^{*}\right) \equiv U\left(y^{*}-h\right)+\beta(X(k) h-\gamma)-U\left(y^{*}-q\right)-\beta(\bar{Q} / Q z) q=0
\end{aligned}
$$

where $z$ represents next period's (known) rate of fiat money creation. Then 


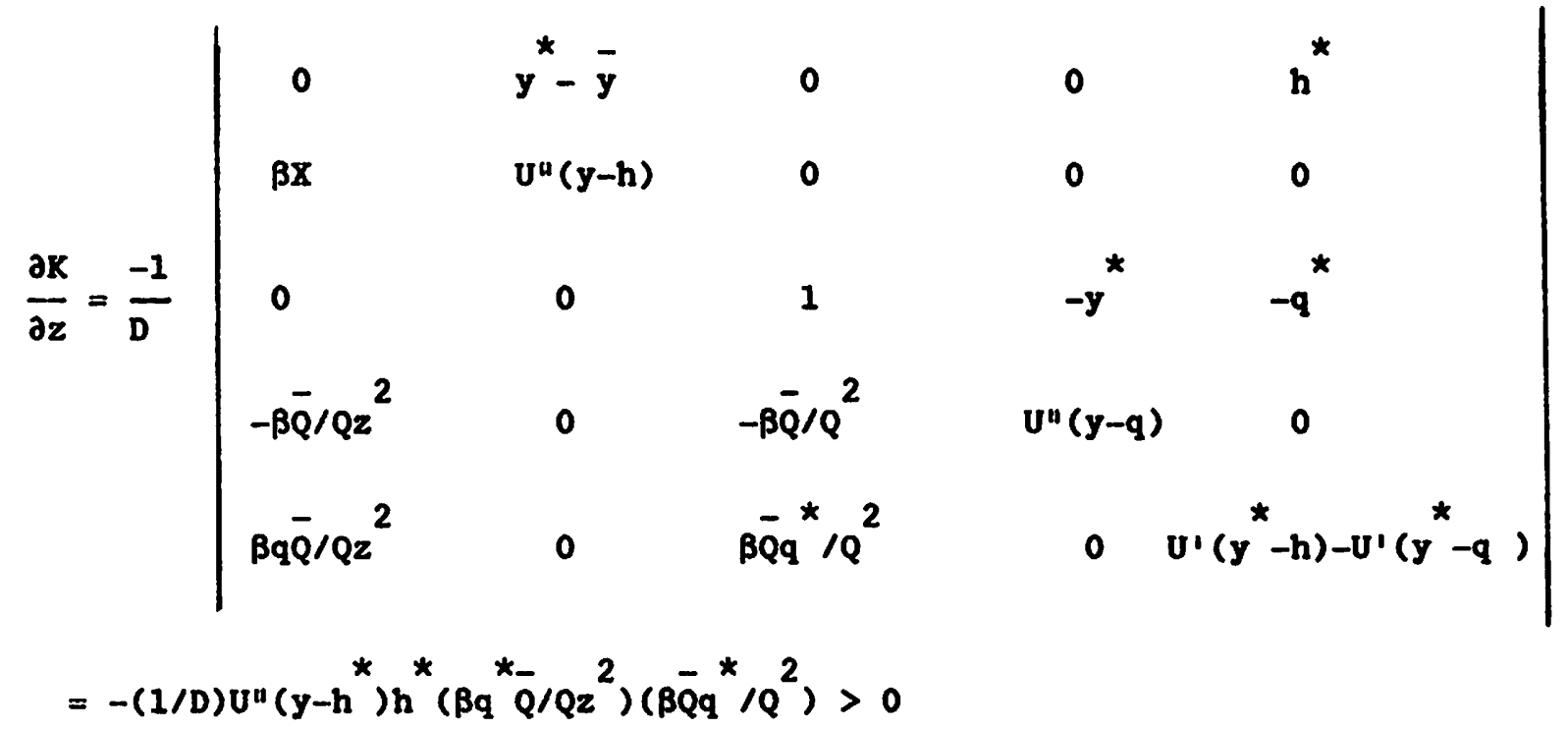

By similar calculations it can be established that $\partial Q / \partial z<0$. Q.B.D. 


\section{APPEADIX B}

In this appendix we construct a simulation of the model used in the paper. The stochastic driving variable for this economy will be shocks to the marginal product of capital $\left(a_{t}\right)$ and to the supply of fiat currency $\left(z_{t}\right)$. Ideally, a stochastic process for $\left\{\alpha_{t}, z_{t}\right\}$ would be specified in such a manner as to permit agents to construct expectations of functions of future values of $\left(\alpha_{t}, z_{t}\right)$. This procedure, however, becomes problematic for the purpose of simulating the model as there are difficulties introduced through equation (5). Agents will forecast the future value of real fiat money holdings $\left(Q_{t+1}\right)$, as can be seen from equation ( 7$)$. However, the mapping from the stochastic process governing $\left\{\alpha_{t}, z_{t}\right\}$ to the process governing $\left\{Q_{t}\right\}$ is nontrivial. Instead we follow a procedure similar to that outlined by sims (1984) in deriving a stochastic process for $a_{t}$ which is consistent with a specific distribution for the endogenous variables.

To this end we let the values of $Q_{t}$ be i.i.d. uniformly in the interval $[1 / 2,2]$. Therefore $E(Q)=1.25$. It is easily seen that this implies that the rate of return on money lies in the interval $[\%, 1.5]$. Let $U(c)=\ln (c)$ and $X(K)=\bar{K}^{-1 / 2}$. By picking $y_{0}=3$ and $\bar{y}=10$ it can be shown that all agents. saving is positive. Substituting the solution for $q(y)$ into the equation

$$
Q=\int_{y_{0}}^{y^{*}} q(y) d y
$$

yields the equilibrium condition for outside money. For each value of $Q \in\left[\frac{1}{2}, 2\right]$ it can be shown that this equation yields a unique value of $y^{*}$ determined by 
$y^{\star}=.8 Q+\left[.64 Q^{2}+9-2.8 Q\right]^{2 / 2}$.

It can be then be shown that $y^{\star} \in[3.185,4.042]$.

The aggregate fiat money supply, set equal to unity in the initial period, is augmented each period. The government increases the supply of currency in order to increase its own consumption. Let $z_{t}=\left(\mathbb{H}_{t} / \mathbb{M}_{t-1}\right)$. It is assumed that $z_{t}$ is a random variable distributed uniformly over the interval $[1,1.05]$. If $K_{t}$ and $Q_{t}$ denote the actual nominal and real quantities, respectively, of fiat currency, then the price level is determined as $P_{t}=\left(H_{t} / Q_{t}\right)$. For a single realization of $Q$, the expected rate of return on fiat money as well as $y^{*}$ are determined, so that equation (5) becomes a single (implicit) equation in the single unknown $x_{t}$. since $k_{t}$ is determined by

$$
k_{t}=\int_{y_{t}^{*}}^{\bar{y}} h(y) d y .
$$

Hence $\alpha_{t}$ is determined as

$$
a_{t}=x_{t} k^{1 / 2}
$$

190 observations were generated with this technique. Variance decompositions for aggregate output have been computed for both a two and three variable system, and the results are presented in Tables 1 and 2 . Table 1 shows that the aggregate money stock can account for up to $28 \%$ of the variability in aggregate output at a forecast horizon of 20 periods, in a two variable autoregressive system. Table 2 then shows that if the nominal interest rate is added to this system, the variability of output which is 
attributable to movements in the aggregate money stock falls to 3\%! The nominal interest rate then accounts for $86 \%$ of the variability in output at a forecast horizon of 20 periods.

The inside money component of the money stock is that part which is useful in predicting output. The outside money stock, which is subject to random shocks, is not useful in predicting output. Hence the aggregate money stock is somewhat useful in predicting output. However, the nominal interest rate, which is strongly positively correlated with inside money, can account for a substantial portion of the variability in output. 


\section{TABLE 1}

Decomposition of Variance of Output at Various Forecast Horizons

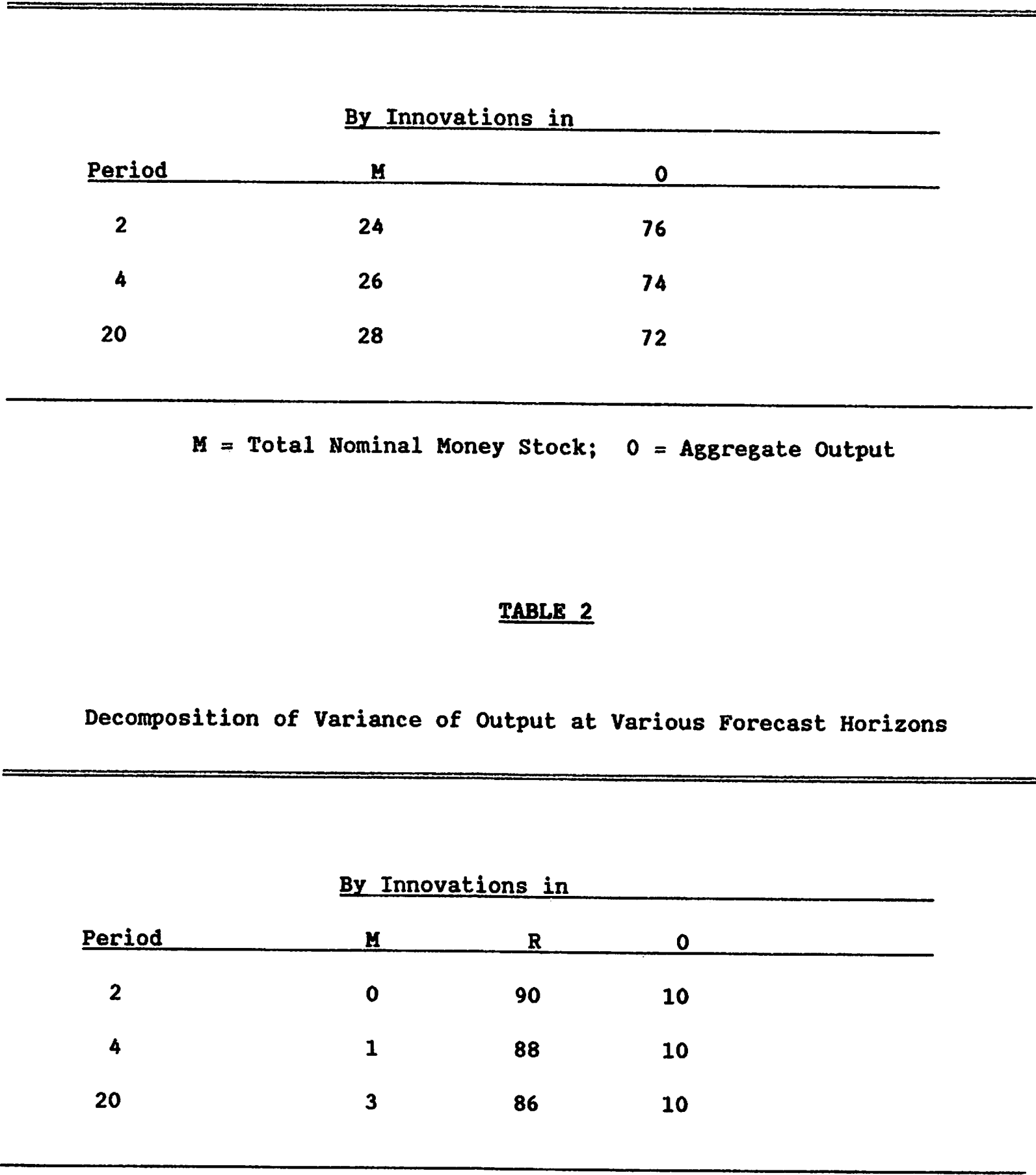

$\mathbf{R}=$ Nominal Interest Rate 


\section{FOOTHOTBS}

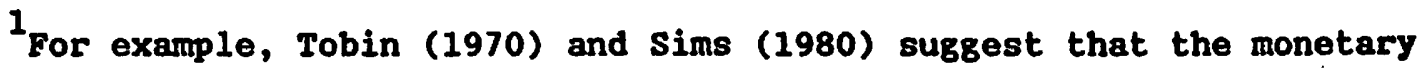
authority may be changing the monetary base in response to economic fluctuations. Lucas (1972) suggests that the surprise increases in the monetary base cause price increases that fool agents into increasing output through the mistaken belief that there is a greater real demand for their product. Hodels which look at inside money as the source of the monetary fluctuations are King and Plosser (1984), Lacker (1986), and Freeman (1986).

2 This strong neutrality depends in part on agents' risk neutrality towards consumption when old. A policy of stabilizing the total nominal money stock will act to reduce the randomness of the price level. Therefore, if agents are risk-averse in consumption when old, fiat money is more desirable because it is a safer asset if the money stock is stabilized. This results in lower levels of capital and output in every period. However, output is still random and uncorrelated with changes in the monetary base.

3 To see this note that the equilibrium conditions representing the demand for money are $F_{2}$ and $F_{4}$ of (7). Their essential properties are that an individual's demand for real balances of either form of money is increasing in both his endowment and the rate of return on money. Therefore, other money demand functions with these properties could easily be substituted. The essence of the model's money/output correlations come from condition $F_{5}$, which determines the relative use of inside and outside money. 


\section{REFEREUCES}

Cagan, Phillip (1965), Determinants and Effects of Changes in the U.S.

Yoney Stock, 1875-1960, New York, National Bureau of Bconomic Research. Freeman, Scott (1986), "Inside Money, Monetary Contractions, and Welfare", Canadian Journal of Economics 19, (February): 87-98.

Friedman, Milton (1968), "The Role of Monetary Policy", American Economic

Review 58 (March): 1-17.

Friedman, Milton and Schwartz, Anna (1963), "Money and Business Cycles", Review of Economics and Statistics 45, (February): 32-64. and (1963), A Monetary History of the United

States, Princeton.

King, Robert and Plosser, Charles (1984), "Honey, Credit, and Prices in a Real Business Cycle", American Economic Review 74 (June): 363-80. Litterman, Robert and Weiss, Lawrence (1985), "Koney, Real Interest Rates and Output: A Reinterpretation of U.S. Postwar Data", Econometrica 53 (January): 129-156.

Lacker, Jeffrey (1986), "Inside Money and Real Output," Krannert Graduate School of Management, Institute Paper No. 887.

Lucas, Robert E. Jr., "Expectations and the Neutrality of Money", Journal of Economic Theory 4 (Apri1): 103-24.

Sargent, Thomas and Wallace, Neil (1982), "The Real-Bills Doctrine vs. The Quantity Theory: A Reconciliation", Journal of Political Economy 90 (December): $1212-36$. 
Sims, C.A. (1972), "Koney, Income, and Causality", American Bconomic

Review 62 (September): 540-52.

(1980), "Comparison of Interwar and Postwar Cycles: Monetarism Reconsidered", American Economic Review 70 (May): 250-7. (1984), "Solving Nonlinear Stochastic Equilibrium Hodels 'Backwards'", University of Minnesota Discussion Paper No. 206. Tobin, James (1970), "Koney and Income: post hoc ergo propter hoc?", Quarterly Journal of Economics 84 310-17. 
8401C Harrison, Glenn W. and Manning, Richard. BEST APPROXIMATE AGGREGATON OF INPUT-OUTPUT SYSTEMS.

8402C Parkin, Michael. CORE INFLATION: A REVIEW ESSAY.

8403C Blomqvist, Àke, and McMahon, Gary. SIMULATING COMMEICAL POLICY IN A SMALL, OPEN DUAL ECONOMY WITH URBAN UNEMPLOYMENT: A GENERAL EQUILIBRIUM APPROACH.

8404C Wonnacott, Ronald. THE THEORY OF TRADE DISCRIMINATION: THE MIRROR IMAGE OF VINERIAN PREFERENCE THEORY?

8405C Whalley, John. IMPACTS OF A 50\% TARIFF REDUCTION IN AN EIGHT-REGION GLOBAL TRADE MODEL.

8406C Harrison, Glenn W. A GENERAL EQUILIBRIUM ANALYSIS OF TARIFY REDUCTIONS.

8407C Horstmann, Ignatlus and Markusen, James R. STRATEGIC INVESTMENTS AND THE DEVELOPMENT OF MULTINATIONALS.

8408C Gregory, Allan W. and McCurdy, Thomas H. TESTING THE UNBIASEDNESS HYPOTHESIS IN THE FORWARD FOREIGN EXCHANGE MARKET: A SPECIFICATION ANALYSIS.

8409C Jones, Ronald W. and Klerzkowsk1, Henryk. NEIGHBORHOOD PRODUCTION STRUCTURES WITH APPLICATIONS TO THE THEORY OF INTERNATIONAL TRADE.

$8410 \mathrm{C}$ Weller, Paul and Yano, Makoto. THE ROLE OF FUTURES MARKETS IN INTERNATIONAL, TRADE: A GENERAL EỌUILIBRIUM APPROACH.

8411C Brecher, Richard A, and Bhagwat1, Jagdish N. VOLUNTARY EXPORT RESTRICTIONS VERSUS IMPORT RESTRICTIONS: A WELFARE-THEORETIC COMPARISON.

8412C Ethier, W11fred J. ILLEGAL IMMIrRATION.

8413C Eaton, Jonathon and Gene M. Grossman. OPTIMAL TRADE AND INDUSTRIAL POLICY UNDER OLIGOPOLY.

8414C Hooton, Ian. PREFERENTIAL TRADING AGREEMENTS - A 3xn MODEL.

8415C Parkin, Michael. DISCRIMINATINF, BETWEEN KEYNESIAN AND

CLASSICAL THEORIES OF THE BUSINESS CYCLE; JAPAN $1967-1282$

8416C Deardorff, Alan V. FIRless FIRwoes: HOW PREFERENCES CAN INTERFERE WITH THE THEOREMS OF INTERNATIONAL TRADE.

8417C Greenwood, Jeremy. NONTRADED GOODS, THE TRADE BALANCE, AND THE BALANCE OF PAYRENTS. 
8418C Blomqvist, Ake and Sharif Mohammad. CONTROLS; CORRUPTION, AND COMPETITIVE RENT-SEEKING IN LDCs.

8419C Grossman, Herschel I. POLICY, RATIONAL EXPECTATIONS, AND POSITIVE ECONOMIC ANALYSIS.

8420C Garber, Peter M. and Robert G. King. DEEP STRUCTURAL EXCAVATION? A CRITIOUE OF EULER EQUATION METHODS.

8421C BarIo, Robert J. THE BEHAVIOR OF U.S. DEFICITS.

8422C Persson, Torsten and Lars E.0. Svensson. INTERNATIONAL BORROWING AND TIME-CONSISTENT FISCAL POLICY.

8423C Obstfeld Maurice. CAPITAL CONTKOLS, THE DUAL EXCHANGE RATE, AND DEVALUATION.

8424C Kuhn, Peter. UNION PRODUCTIVITY EFFECTS AND ECONOMIC EFFICIENCY.

8425C Hamilton, Bob and John Whalley. TAX TREATMENT OF HOUSING IN A DYNAMIC SEOUUENCED GENERAL EOUUILIBRIUM MODEL.

$\because 426 \mathrm{C}$ Hamilton, Bob, Sharif Mohammad, and John Whalley. RENT SEEKING AND THE NORTH-SOUTH TERMS OF TRADE.

8427C Adams, Charles and Jeremy Greenwood. DUAL EXCHANGE RATE SYSTEMS AND CAPITAL CONTROLS: $\Lambda$ N INVESTIGATION.

8428 Loh, Choon Cheong and Michael R. Veall. A NOTE ON SOCIAL SECURITY AND PRIVATE SAVINGS IN SINGAPORE.

8429 Whalley, John. REGRESSION OR PROCRESSION: THE TAYING OUESTION OF INCIDENCE ANALYSIS.

8430 Kuhn, Peter. WAGES, EFFORT, AND INCENTIVE-COMPATIBILITY IN LIFE-CYCLE EMPLOYMENT CONTRACTS.

8431 Greenwood, Jeremy and Kent P. Kimbrough. AN INVESTIGATION IN THE THEORY OF FOREICN EXCLANGE CONTROLS.

8432 Greenwood, Jeremy and Kent P. Kimbrough. CAPITAL CONTROLS AND THE INTERNATIONAL TRANSMISSION OF FISCAL POLICY.

8433 : Nguyen, Trien Trien and John Whalley. EỌUILIBRIUM UNDER PRICE CONTROLS WITH ENDOGENOUS TRANSACTIONS COSTS.

8434 Adams, Charles and Russell S. Boyer. EFFICIENCY AND A SIMPLE MODEL OF EXCHANGE RATE DETERMINATION. 
8435 Kuhn, Peter. UNIONS, ENTREPRENEURSHIP, AND EFFICIENCY.

8436 Hercowitz, Zv1 and Efraim Sadka. ON OPTIMAL CURRENCY. SUBSTITUTION POLICY AND PUBLIC PINANCE.

8437 Lenjosek, Gordon and John Whalley, POLICY EVALUATION IN A SMALL OPEN PRICE TAKING ECONOMY: CANADIAN ENERGY POLICIES.

8438 Aschauer, David and Jeremy Greenwood. MACROECONOMIC EFFECTS OF FISCAL POLICY.

8439C Hercowitz, ZVI. ON THE DETERMINATION OF THE EXTERNAL DEBT: THE CASE OF ISRAEL.

8440C Stern, Robert M. GLOBAL DIMENSIONS AND DETERMINANTS OF INTERNATIONAL TRADE AND INVESTMENT IN SERVICES.

8441C Deardorff, Alan V. COMPARATIVE ADVANTAGE AND INTERNATIONAL TRADE AND INVESTMENT IN SERVICES.

8442C Daly, Donald J. TECHNOLOGY TRANSFER AND CANADA'S COMPETITIVE PERFORMANCE.

8443C Grey, Rodney de C. NEGOTIATING ABOUT TRADE AND INVESTMENT IN SERVICES.

8444C Grossman, Gene M. and Carl Shapiro. NORMATIVE ISSUES RAISED BY INTERNATIONAL TRADE IN TECHNOLOGY SERVICES.

3445C Chant, John F. THE CANADIAN TREATMENT OF FOREIGN BANKS: A CASE STUDY IN THE WORKINGS OF THE NATIONAL TREATMENT APPROACH.

8446C Aronson, Jonathan D. and Peter F. Cowhey - COMPUTER, DATA PROCESSING, AND COMMUNICATION SERVICES.

8447C Feketakuty, Geza. NEGOTIATING STRATEGIES FOR LIBERALIZING TRADE AND INVESTMENT IN SERVICES.

8448C Harrison, Glenn, W. and E.E. Rutstrom. THE EFFECT OF MANUTACTURING SECTOR PROTECTION ON ASEAN AND AUSTRALIA: A GENERAL ENUUILIBRIUM ANALYSIS. 
8501C Greenwood, Jeremy and Kent P. Kimbrough. FOREIGN EXCHANGE CONTROLS IN A BLACK MARKET ECONOMY.

8502C Horstmann, Ignatius and James R. Markusen. UP YOUR AVERAGE COST CURVE: INEFFICIENT ENTRY AND THE NEW PROTECTIONISM.

8503C Gregory, Allan $W$. TESTING INTEREST RATE PARITY AND RATIONAL EXPECTATIONS IROR CANADA AND THE UNITED STATES.

8504C Kuhn, Peter and Ian Hooton. INTERNATIONAL FACTOR MOVEMENTS IN THE PRESENCE OF A FIXED FACTOR.

8505C Wong, Kar-yIu. GAINS FROM GOODS TRADE AND FACTOR MOBIIITY.

8506C Weller, Paul and Makoto Yano. FUTURES MARKETS, REAL INCOME, AND SPOT PRICE VARIABILITY: A GENERAL EỌUILIBRIUM APPROACH.

8507C Dlewert, W.E. THE EFFECTS OF AN INNOVATION: A TRADE THEORY APPROACH.

8508C Ethier, Wilfred J. FOREIGN DIRECT INVESTMENT AND THE MULTINATIONAL FIRM.

8509C Dinopoulos, Elias. INSIDE THE BLACK BOX: (IN) TANGIBLE ASSETS, INTRA-INDUSTRY INVESTMENT AND TRADE.

8510C Jones, Richard, John Whalley, and Randall Higle. REGIONAL IMPACTS OF TARIFFS IN CANADA: PRELIMINARY RESULTS FROM A SMALL DIMENSIONAL NUMERICAL GENERAL EOUUILIBRIUM MODEL.

8511C Whalley, John. HIDDEN CHALLENGES IN RECENT APPLIED GENERAL EQUILIBRIUM EXERCISES.

8512C Smith, Bruce. SOME COLONIAL EVIDENCE ON TWO THEORIES OF MONEY: MARYLAND AND THE CAROLINAS.

3513C Grossman, S.J., A. Melino, and R.J. Shlller. ESTIMATING THE CONTINUOUS TIME CONSUMPTION BASED ASSET PRICING MODEL.

8514C Romer, Paul R. TAX EFFECTS AND TRANSACTION COSTS FOR SHORT TERM MARKET DISCOUNT BONDS. .

8515C McCallum, Bennett T. ON CONSEOUENCES AND CRITJCISMS OF MONETARY TARGETING.

8516C Dinopoulos, Ellas and Ian Wooton. A NORTH-SOUTH MODEL OF INTERNATIONAL JUSTICE.

8517C Huffman, Gregory W. A DYNAMIC EQUILIBRIUM MODEL OF ASSET PRICES AND TRANSACTION VOLUME.

8518C Huffman, Gregory W. AN ALTERNATIVE VIEW OF OPTIMAL SEIGNIORAGE.

8519C Huffman, Gregory W. ASSET PRICING WITH HETERGENEOUS ASSETS. 
8520C Hercowitz, Zvi. THE REAL INTEREST RATE AND AGGREGATE SUPPLY.

$8521 \mathrm{C}$ Davies, James and Michael Hoy. COMPARING INCOME DISTRIBUTIONS UNDER AVERSION TO DOWNSIDE INEQUALITY.

8522C Nguyen, Trien T. and John Whalley. COEXISTENCE OF EQUIIIBRIA ON BLACK AND WHITE MARKETS.

8523C Clarete, Ramon and John Whalley. INTERACTIONS BETWEEN TRADE POLICIES AND DOMESTIC DISTORTIONS: THE PHILIPPINE CASE.

8524C Hamilton, Bob, Sharif Mohammad, and John Whalley. APPLIED GENERAL EQUIL IBRIUM ANALYSIS AND PERSPECTIVES ON GROWTH PERFORMANCE.

852.5C Huffman, Gregory W. THE LAGGED EFFECTS OF POLICY ON THE PRICE LEVEL.

85:6C Laidler, David. FISCAL DEFICITS AND INTERNATIONAI MONETARY INSTITUTIONS.

8.527C Goodfriend, Marvin. MONETARY MYSTIQUE: SECRECY AND CENTRAL BANKING.

8528C Nguyen, Trien T. and John Whalley. GENERAL EQUILIBRIUM ANALYSIS OF PRICE CONTROLS A TWO-SECTOR COMPUTATIONAL APPROACH.

8529C Heckman, James $\mathrm{J}$. and $\mathrm{V}$. Joseph Hotz. AN INVESTIGATION OF THE LABOR MARKET EARNINGS OF PANAMANIAN MALES: EVALUATING SOURCES OF INEQUALITY.

8530C Greenwood, Jeremy and Gregory W. Huffman. A DYNAMIC EQUIIIBRIUM MODEL OF INFLATION AND UNEMPLOYMENT.

8531C Freeman, Scott. INSIDE MONEY, MONETARY CONTRACTIONS, AND WELFARE.

8532C Paderanga, Cayetano Jr. and Ian Wooton. A POSITIVE VIEW OF INF'ANT INDUSTRIES.

8533C St--Hilaire, France and John Whalley. A MICROCONSISTENT DATA SE'I FOR CANADA FOR USE IN REGIONAL GENERAL EQUII IBRIUM POLICY AN.ALYSIS.

8534C Whalley, John. OPERATIONALIZING WALRAS: EXPERIENCE WITH RECENT A'PPLIED GENERAL EQUILIBRIUM TAX MODELS.

8535C Melvin, James R. THE GENERAL NON-EQUIVALENCE OF TARIFFS AND ILMPORT QUOTAS. 
8601C Greenwood, Jeremy and R. Preston McAfee. EXTERNALITIES AND ASYMETRIC INFORMATION.

8602C Dinopoulos, Elias and Mordechal E. Kreinin. IMPORT OUUOTAS AND VERS: A COMPARATIVE ANALYSIS IN A THREE-COUNTRY FRAMEWORK.

8603C Clarete, Ramon and John Whalley. COMPARING THE MARGINAL WELFARE COSTS OF COMMODITY AND TRADE TAXES.

8604C Wigle, Randy. CANADIAN TRADE LIBERALIZATION: SCALE ECONOMIES IN A GLOBAL CONTEXT.

8605C Parkin, Michael. DOMESTIC MONETARY INSTITUTIONS AND FISCAL DEFICITS.

8606C Dinopoulos, Elias and Ian Wooton. INTERNATIONAL TRADE AND THE ACQUISITION OF SKILLS.

8607C Kawasaki, Selichi and John McMillan. THE DESIGN OF CONTRACTS: EVIDENCE FROM JAPANESE SUBCONTRACTING.

8608C Williamson, Stephen D. LIQUIDITY, BANKING, AND BANK FAIIURES.

8609C Grossman, Gene M. and Carl Shapiro. COUNTERFEIT-PRODUCT TRADE.

8610C Deardorff, Alan V. WHY DO GOVERNMENTS PREFER NONTARIFF BARRIERS?

8611C Horstmann, Ignatius and James R. Markusen. LICENSING VERSUS DIRECT INVESTMENT: A MODEL OF INTERNALIZATION BY THE MULTINATIONAL ENTERPRISE.

8612C Thursby, Jerry G. and Marie C. Thursby. BIIATERAL TRADE FLOWS, THE LINDER HYPOTHESIS, AND EXCHANGE RISK.

8613C Clarete, Ramon and John Whalley. EQUIIIBRIUM IN THE PRESENCE OF FOREIGN EXCHANGE PREMIA.

8614C Wooton, Ian. TOWARDS A COMMON MARKET: FACTOR MOBILITY IN A CUSTOMS UNION.

8615C St-Hilaire, France and John Whalley. SOME ESTIMATES OF TRADE FLOWS IN BANKING SERVICES.

8616C Evenson, Robert E. and Cayetano Paderanga Jr. RURAL LABOUR MARKETS, TRANSACTION COST AND PERTILITY.

8617C Fried, Joel and Peter Howitt. FISCAL DEFICITS, INTERNATIONAL TRADE AND WELFARE.

8618C Trela, Irene, John Whalley, and Randy Wigle. INTERNATIONAL TRADE IN AGRICULTURE: DOMESTIC POLICIES, TRADE CONFLICTS, AND NEGOTIATING OPTIONS. 
8619C Markusen, James R. and Anthony J. Venables. TRADE POLICY WITH INCREASING RETURNS AND IMPERFECT COMPETITION: CONTRADICTORY RESULTS FROM COMPETING ASSUMPTIONS.

8620C Hunter, Linda and James R. Markusen. PER-CAPITA INCOME AS A DETERMINANT OF TRADE.

8621C Jones, Rich and John Whalley. A CANADIAN REGIONAL GENERAL EQUILIBRIUM MODEL AND SOME APPLICATIONS.

8622C Freeman, Scott, and Gregory W. Huffman. INSIDE MONEY, OUTPUT, AND CAUSALITY. 